\title{
Endometriosis-Associated Infertility
}

Elena-Silvia Nada', Lacramioara Brinduse ${ }^{2,3}$, Ovidiu Bratu²,4, Dragos Marcu ${ }^{2,4}$, Elvira Bratila1,2

\begin{abstract}
Endometriosis is a heterogeneous disease, affecting women during their reproductive period. The most frequent clinical manifestations include dysmenorrhea, dyspareunia, chronic pelvic pain and infertility. Endometriosis interferes in all the steps of the reproductive process, from folliculogenesis till implantation. Medical treatment of women who desire fertility is contraindicated as it delays conception. Surgery has proven to be an important step in managing these patients along with IVF. Despite the detrimental effects of endometriosis upon the reproductive process, IVF represents the best option when dealing with infertility.
\end{abstract}

Keywords: endometriosis, infertility, pregnancy rate, IVF

\section{Rezumat}

Endometrioza este o afecțiune heterogenă care afectează femeile în timpul perioadei reproductive. Cele mai frecvente manifestări clinice includ dismenoreea, dispareunia, durerea pelvină cronică și infertilitatea. Endometrioza afectează toate etapele procesului de reproducere, de la foliculogeneză până la implantare. Tratamentul medicamentos al femeilor care doresc o sarcină este contraindicat deoarece întârzie concepția. Chirurgia este o etapă importantă în gestionarea acestor paciente împreună cu FIV. În ciuda efectelor negative ale endometriozei asupra procesului reproductiv, FIV reprezintă cea mai bună opțiune pentru tratarea infertilității.

Cuvinte cheie: endometrioză, infertilitate, rată de sarcină, FIV

\section{INTRODUCTION}

Endometriosis is definined as the presence of endometrial-like tissue outside the uterine cavity and it presumably affects $10-15 \%$ of reproductive aged women. The prevalence of endometriosis appears to be higher in women in Philippines, Indian, Japanese and Korean origin. ${ }^{1}$ Clinical manifestations depend upon the site where the ectopic endometrial tissue is located and include dysmenorrhea, dyspareunia, chronic pelvic pain, infertility, but the possibility of being asymptomatic exists. A major drawback that could result in late diagnosis and management is the lack of correlation between symptoms and disease severity ${ }^{1,2}$.

Transvaginal sonography is the main imagistic investigation used with high specificity and sensitivity in diagnosing endometriomas, urinarry bladder endometriosis, but with low sensitivity in detecting endometriotic lesions in the posterior pelvic compartment. Sonovaginography with ultrasound gel has proven to be a useful investigation tool for identification of posterior pelvic compartment endometriosis (rectovaginal septum, posterior vaginal fornix, uterosacral ligaments). When deep infiltrating endometriosis is suspected so-

\footnotetext{
${ }^{1}$ "Dr Panait Sarbu" Hospital of Obtetrics and Gynaecology, Bucharest, Romania

2 "Carol Davila" University of Medicine and Pharmacy, Bucharest, Romania

${ }^{3}$ Department of Public Health and Management, Bucharest,

Romania

${ }^{4}$ Clinic of Urology, Emergency University Central Military Hospital,

Bucharest, Romania

${ }^{5}$ Academy of Romanian Scientists
}

\section{Corresponding author.}

Elvira Bratila, „Dr Panait Sarbu” Hospital of Obtetrics and Gynaecology, Bucharest, Romania.

E-mail: elvira.bratila@umfcd.ro 
novaginography with ultrasound gel should be performed in conjunction with transvaginal sonography ${ }^{3}$.

Another challenge is diagnosing colorectal endometriosis. This is one of the most severe forms of the disease and it is almost impossible to detect at physical examination alone, especially when the implants are located above the sigmoid colon ${ }^{4}$. Magnetic resonance imaging is considered an useful diagnostic tool in this situation, but recently a different approach has been studied. The combination of magnetic resonance imaging and computed tomography-based virtual colonoscopy leads to greater accuracy in the assessment of both small and large bowel endometriosis ${ }^{5,6}$.

The pathogenesis of endometriosis is mainly explained by various theories. The most well known and accepted theory is the one proposed by Sampson in 1920' which states that during menstruation, a certain number of endometrial cells migrate via the tubal ostia into the peritoneal cavity where they attach, proliferate and create an independent blood supply ${ }^{2,7}$. However, not all women with retrograde menstruation have endometriosis, so other factors must contribute to its development. Retrograde menstruation has a higher prevalence in women with congenital mullerian anomalies.

Another theory states that ectopic endometrial implants arise from coelomic metaplasia. This was proposed by Ferguson in the $1960^{22,7}$. The coelomic cells in the peritoneum can differentiate into endometrial cells due to undetermined stimuli. One important contributing factor is altered immunity. Patients with endometriosis have an altered cell mediated immnity translating into defective activity of leukocytes and NK-cells. This prevents the proper clearance of the refluxed endometrial cells ${ }^{7}$.

Rare extraperitoneal locations of endometriosis such as pulmonary, cerebral or umbilical cannot be explained neither by retrograde menstruation nor by coelomic metaplasia, but by lymphovascular spread of viable endometrial cells. Secondary umbilical endometriosis is unusual and is mainly associated with abdominal surgery involving the umbilicus, but primary umbilical endometriosis (Villar's nodule) is even more uncommon. Few such cases have been reported, so the pathogenesis of this condition is controversial. Some theories imply that the endometrial cells migrate to the umbilicul through the abdominal cavity, the lymphatic system and the umbilical vessels or the endometrial cells proliferate from initial extraperitoneal disease along the urachus ${ }^{8,9}$.

Migration of endometrial cells in retroperitoneum can develop symptomatology similar with any mass in that region ${ }^{10-17}$, affecting by infiltration or compression many anatomical structures ${ }^{18-24}$.

Another possible pathogenesis of endometriosis comes from newer research in stem cells. It was proven that de novo endometrial tissue can develop from endogenous stem cells $s^{6,7}$. In a study dating back from 2004 it was demonstrated that female bone marrow transplant recipients who received bone marrow from a single mismatched related donor had donor-derived endometrial cells in endometrial biopsies ${ }^{25}$. This implies that non-uterine stem cells can regenerate endometrial tissue, but may also lead to ectopic implants.

\section{INFERTILITY IN ENDOMETRIOSIS}

Endometriosis is a leading cause of infertility through various mechanism, but not all women with endometriosis have a difficulty in conceiving.

The main mechanism is the altered anatomy. Pelvic adhesions lead to impaired oocyte release and ostial pick-up, altered sperm mobility, myometrial contractions which in turn lead to altered embryo transport and fertilization. In fact, endometriosis affects all stages of the reproduction process. The inflammatory cells in the peritoneal fluid and endometriomas have damaging effects upon the oocyte, embryo and sperm, impair tubal function and decrease tubal mobility ${ }^{7}$. All this leads to a lower fertilization rate both in natural and in vitro cycles.

The ectopic endometrial cells interact with immune mechanisms, the starting point is the activation of repairing mechanisms of the destroyed tissue. Inflammatory mediators are released by macrophages, dendritic cells and mast cells leading to vasodilation, increased endothelial permeability and extravasation of white blood cells. In the peritoneal fluid there are elevated levels of interleukines (IL 1, 6, 7, 8, 17) TNF $\alpha$, VEGF which create a hostile environment for folliculogenesis, sperm and implantation ${ }^{1,7,26}$.

Even superficial peritoneal implants produce inflammatory cytokines and chemokines causing an increased oxidative stress and an altered hormonal profile. The endometriomas directly affect folliculogenesis leading to poor oocyte and embryo quality and also poor response during ovarian stimulation ${ }^{27}$. Hemolysis of trapped blood leads to high iron level within the cyst suggesting cytotoxic oxidative stress ${ }^{1}$.

Endometriosis negatively affects the physiology of granulosa cells, leading to increased apoptosis and alteration of steroidogenesis by decreasing the expressi- 
on of aromatase. This causes an imbalance in estrogen production, lower estradiol concentration at the preovulatory stage and at the $\mathrm{LH}$ surge. The duration of the follicular phase is extended in these patients, as the LH surge is delayed or biphasic leading to an altered postovulatory progesterone secretion that might affect oocyte maturation $^{1,28}$.

Endometriosis modifies the follicular oxidative stress status and the subsequent reactive oxygen species produce meiotic abnormalities and chromosomic instability and thereby reducing the oocyte quality. These oocytes have a streghtened zona pellucida and this might affect fertilization, dissolution of the zona pellucida and the ability of the embryo to undergo hatching and implantation. Studies in this field are somewhat limited due to ethical reasons and the oocyte quality was mostly studied indirectly by evaluating the cumulus cells and the follicular fluid ${ }^{28}$.

Recently, the spindle morphology is used as a marker of oocyte quality. A study from 2014 revealed that the oocytes retrieved from women with endometriosis had a higher percentage of spindle abnormalities compared to women undergoing IVF due to male factor $(66.7 \%$ versus $16 \%$ ) as well a higher apoptosis level ( $80 \%$ versus $22.2 \%)^{28,29}$.

Cytoplasm composition is another indicator of oocyte and embryo development. Compared to other cells, the cytoplasm of mature oocytes has a higher mitochondrial content, up to 105 mitochondria. It was discovered that the oocytes of women with endometriosis have a higher percentage of abnormal mitochondria and a lower number overall $(84.6 \pm 39.8$ versus $50.7 \pm 288.5)^{27,30}$.

Effects of endometriosis upon the endometrium are also of great importance. A study from 2012 proved that cells can migrate from ectopic endometrial implants back to the uterine endometrium. These migrating cells had a Wn7A up-regulation expression which led to endometrial disturbance during implantation window. The Wn7A gene is involved in estrogen-mediated uterine growth and implantion ${ }^{7,31}$. Another gene involved is the Hoxa ${ }^{10}$. Cyclical endometrial expression of this gene leads to endometrial regeneration. Women with endometriosis have lower levels of the Hoxa ${ }^{10}$ gene and this could explain the lower implantation rates. Lower implantation rates are also attributed to high levels of matrix metalloproteinase which cause persistent endometrial breakdown and low levels of $\alpha \beta$-integrin which impair embryo attachment ${ }^{7}$.

\section{MEDICAL MANAGEMENT}

Current available treatment options for endometriosis mainly address pain. These incluse combined oral contraceptives, progestins, androgens, $\mathrm{GnRh}$ agonists ${ }^{2,32}$. All of them aim at reducing the circulating estrogen levels, but no do not have any effect upon infertility. Moreover, they delay the moment of conception, so they are not considered an option for women desiring a pregnancy. A valid example is depot medroxyprogesterone acetate. Although it is highly effective in relieving pain, it has lasting effects upon ovulation suppresion long beyond the duration of treatment 33 . A exception to this are women undergoing in vitro fertilization. It was proven that $\mathrm{GnRh}$ agonist treatment before ovarian stimulation leads to increased oocytes and higher implantation rates. However a review from 2010 stipulated that although pretreatment with $\mathrm{GnRh}$ agonists led to an improved ovarian response and a greater number of mature oocytes, it did not increase the overall pregnancy rate. ${ }^{7}$

\section{SURGICAL MANAGEMENT}

Nowadays it is generally accepted that laparoscopy is the gold standard in endometriosis, as it is both diagnostic and therapeutic. However, the decision to operate a patient with endometriosis should be tailored according to the individual's characteristics: age, symptoms, stage of disease, ovarian reserve, length of infertility, associated factors of infertility. Taking all of them into account this patient has to be managed by a multidisciplinary team, including a gynecologist, a general surgeon, a fertility specialist and a radiologist. The benefits of surgery are the restoration of normal pelvic anatomy, excision of endometriotic implants and ovarian endometriomas, thus reducing the inflamatory milieu.

An important aspect has to be taken into consideration when dealing with a patient with endometriosis wishing to conceive: counselling the patient about her real changes to conceive before and after surgery ${ }^{27}$. A well known detrimental effect of surgery is the further decline in ovarian reserve in an already infertile patient. Retrospective studies have demonstrated a significantly lower antral follicle count and ovarian volume after laparoscopic excision ${ }^{33}$.

Fertility specialists have stipulated that medical treament with $\mathrm{GnRh}$ agonists after surgery improves pregnancy rates in women with endometriosis undergoing IVF (in vitro fertilization). When taking account 
the technique used, it seems that excisional surgery is associated with better spontaneous pregnancy rates in a 9-12 months interval as opposed to ablative surgery ${ }^{27}$. Two randomized control studies of laparoscopic management of endometriomas have demonstrated an increased pregnancy rate when performing cyst wall excision as opposed to cyst wall ablation, with pregnancy rates of $61 \%$ versus $23.4 \%$ after a two year interval ${ }^{33}$.

Deep infiltrating endometriosis (DIE) also negatively affects pregnancy rates. A retrospective study from 2009 compared the IVF results in women with DIE submitted to laparoscopic treatment before IVF to women not operated before IVF. The study included 179 women divided in two groups, IVF only (105) and surgery and IVF (64). The pregnancy rates were 2.45 times higher in the group of women submitted to surgery before IVF. When DIE is associated with endometriomas, the pregnancy rate is declined furthermore, as compared to DIE alone ( $82.5 \%$ versus $69.4 \%)^{27,34,35}$.

A new scoring system has proved useful in the last years, the endometriosis fertility index (EFI). EFI is used for the prediction of fertility following surgery. It has a more positive correlation when estimating the pregnancy rate than AFS (American Fertility Society) classification. Patients with EFI $>5$ after twelve months from surgery are candidates for IVF ${ }^{1,36}$.

Following surgery it is important to offer hormonal treatment until the woman decides to procreate because endometriosis is a chronic relapsing disease. Studies have shown that an individualised approach is needed forasmuch as the laparoscopic description of the ectopic implants does not offer adequate information about the aggressiveness or the progression capacity of the disease. One direction is choosing the treatment based on the molecular markers identified in the ectopic implants using immunohistochemistry: estrogen receptors, progesterone receptors, the cellular proliferation marker Ki-67 and the marker of inhibition of cellular apoptosis Bcl-2. Estrogen and progesteron receptors expression is modified in endometriotic implants compared with normal endometrium. The low expression of the hormonal receptors could explain the persistence of symptoms and the progression of the disease under hormonal treatment ${ }^{37,38,39}$.

\section{ENDOMETRIOSIS AND IVF}

Treatment options in managing infertility associated with endometriosis include surgical intervention and ovarian stimulation with IVF. As stated above, endo- metriosis negatively impacts preganancy rates in natural and in vitro cycles, but still IVF is the best chance for a woman to get pregnant. A meta-analysis of 22 studies including over 2000 in vitro cycles of women with endometriosis and over $4000 \mathrm{IVF}$ cycles for other causes of infertility proved that fertilization rates, implantation rates and pregnancy rates were all lower in the endometriosis group ${ }^{33}$.

In patients with stage I/II endometriosis IVF is the best option for an increased pregnancy rate, but it is not clear whether surgery would further improve the outcome in this scenario. But a study from 2015 strongly recommends surgery as a first line tool before IVF even in minimal-mild endometriosis, as it doubles the pregnancy rate. Also, in patients who failed to conceive spontaneously after surgery, IVF is more effective than repeat surgery ${ }^{40}$. Pregnancy rates are improved when $\mathrm{GnRh}$ agonists are administered prior to IVF, but don't have any beneficial effect upon women aiming at spontaneous conception, while also adding an unwanted time delay ${ }^{1}$. After $\mathrm{GnRh}$ agonists administration, higher FSH doses and a longer stimulation period are required.

When dealing with older women, surgery may not be the first option, as it leads to a decline in ovarian reserve, except for cases with large ovarian masses which intercept the access to the ovary during oocyte pick$u^{1}$.

Oocyte donation programs can be taken into consideration as a last resort. Patients with endometriosis have a similar implantation and pregnancy rate as other recipients when the oocytes came from healthy donors. However, patients who receive embryos derived from endometriotic ovaries display a lower implantation rate and presumably this is derived from the oocyte qua$\operatorname{lity}^{28}$.

\section{CONCLUSION}

Endometriosis is a heterogeneous disease with numerous implications in the reproductive process, including mechanical, molecular and genetical. The best method for treatment of infertility is IVF, but the decision should be made on an individual basis, also taking into account the age, ovarian reserve, other causes of infertility, duration of infertility and the male partner. Undoubtedly the management of these patients should be done by a multidisciplinary team. 


\section{Compliance with ethics requirements:}

The authors declare no conflict of interest regarding this article.

\section{References}

1. Vassilopoulou L, Matalliotakis M, Zervou MI, Matalliotaki C, Spandidos DA, Matalliotakis I, Goulielimos GN. Endometriosis and in vitro fertilisation Exp. Ther. Med. 2018 Aug; 16 (2): 10431051

2. Bodean O, Voicu D, Munteanu O, Brătilă E, Bohâlțea R, Davițoiu D, Cîrstoiu M. Chronic Pelvic Pain And Endometriosis. Research and Science Today, No 2 (10)/2015: 206-214

3. Brătilă $E$, Comandașu $D E$, Coroleucă $C$, Cârstoiu MM, Berceanu C, Mehedinț C, Brătilă P, Vlădăreanu S. Diagnosis of endometriotic lesions by sonovaginography with ultrasound gel. Med Ultrason 2016; 18: 469-474

4. Brătilă E, Comandașu $D$, Coroleucă $C$, Cîrstoiu $M$, Bohîlțea R, Mehedințu C, Vlădăreanu S, Berceanu C Gastrointestinal symptoms in endometriosis correlated with the disease stage. ISI Proceedings XXXVIth National Congress of Gastroenterology, Hepatology and Digestive Endoscopy, Filodiritto Editore 2016: 67-71

5. Mehedințu C, Brîndușe L, Brătilă E, Monroc M, Lemercier E, Suaud O, Collet-Savoye C, Roman H. Does Computed Tomography-Based Virtual Colonoscopy Improve the Accuracy of Preoperative Assessment Based on Magnetic Resonance Imaging in Women Managed for Colorectal Endometriosis. JMIG 2018; 25: 1009-1017

6. Constantin V, Carâp A, Bobic S, Păun I, Brătilă E, Socea B, Moroșanu AM, Mirancea N. Accurate Diagnosis of Sigmoid CoIon Endometriosis by Immunohistochemistry and Transmission Electron Microscopy- Case Report. Chirurgia (2015) 110: No 5, September - October 482-485

7. Macer ML, Taylor HS Endometriosis and Infertility: A review of the pathogenesis and treatment of endometriosis-associated with infertility. Obstet. Gynecol. Clin. North Am. 2012 Dec; 39 (4): 535-549

8. Brătilă E, Ionescu OM, Badiu DC, Berceanu C, Vlădăreanu S, Pop DM, Mehedintu C Umbilical hernia masking primary umbilical endometriosis - a case report. Rom J. Morphol Embryol 2016, 57 (2 Suppl): 825-829

9. Antonovici M, Ionescu S, Ionescu O, Brătilă E, Mehedințu C, Plotogea M. Extrapelvic endometriosis- our experience. Ginecologia.ro, Anul III, Nr 10, Decembrie 2015 (4/2015) 34-36

10. Value of ultrasound elastography in the diagnosis of native kidney fibrosis - Peride I, Rădulescu D, Niculae A, Ene V, Bratu OG, Checherită IA. - Med Ultrason. 2016 Sep;18(3):362-9

11. Calcific uremic arteriolopathy in hemodialyzed patients. - Checheriță IA, Smarandache D, Rădulescu D, Peride I, Bratu O, Ciocâlteu A, Sebe I, Lascăr I. - Chirurgia (Bucur). 2013 Sep-Oct; 108(5):736-40

12. Difficulties in diagnosis and surgical treatment of a giant retroperitoneal lipoma. - Constantinoiu S, Bârlă R, Iosif C, Cociu L, Gîndea C, Hoară P, Bratu O, Ruşitoru L. - Chirurgia (Bucur). 2009 May-Jun;104(3):363-7

13. Renal artery bilateral arteriosclerosis cause of resistant hypertension in hemodialysed patients. - Niculae A, Peride I, Marinescu-Paninopol A, Vrabie CD, Ginghină O, Jecan CR, Bratu OG

14. Vitamin $K$ influence on cardiovascular mortality in chronic hemodialysed patients - Rădulescu D, Balcangiu Stroescu A, Pricop C, Geavlete B, Negrei C, Bratu O, Ginghină O, Văcăroiu I - Revista de Chimie, vol. 68, nr. 1, 2017
The authors declare that all the procedures and experiments of this study respect the ethical standards in the Helsinki Declaration of 1975, as revised in 2008(5), as well as the national law. Informed consent was obtained from all the patients included in the study.

15. Mullerianosis of the urinary bladder: a rare case report and review of the literature - Stanimir M, Chiutu LC, Wese S, Milulescu A, Nemes RN, Bratu O - Rom J Morphol Embryol. 2016;57(2 Suppl):849-852.

16. Nephrotic syndrome secondary to amyloidosis in a patient with monoclonal gammopathy with renal significance (MGRS) - Andrei Niculae, Ileana Peride, Vlad Vinereanu, Daniela Rădulescu, Ovidiu Gabriel Bratu, Bogdan Florin Geavlete, Ionel Alexandru Checheriță - Rom J Morphol Embryol. 2017;58(3).

17. Synthesis and Characterization of Novel $\mathrm{Cu}(\mathrm{II}), \mathrm{Pd}(\mathrm{II})$ and $\mathrm{Pt}(\mathrm{II})$ Complexes with 8-Ethyl-2-hydroxytricyclo(7.3.1.0(2,7))tridecan -13-one-thiosemicarbazone: Antimicrobial and in Vitro Antiproliferative Activity. - Pahontu E, Paraschivescu C, llies DC, Poirier D, Oprean C, Păunescu V, Gulea A, Roșu T, Bratu O. - Molecules. 2016 May 21;21(5). pii: E674. doi: 10.3390/molecules21050674.

18. Solitary cecum diverticulitis - A surprising diagnosis - Bogdan Socea, Anca A. Nica, Cristian A. Smaranda, Alexandru C. Carâp, Laura I. Socea, Mihai Dimitriu, Ovidiu G. Bratu, Cezar E. Moculescu, Serban V.G. Berteșteanu, Vlad D. Constantin - Archives of the Balkan Medical Union, Vol. 52, Iss. 4, 2017

19. Incidental finding of a sigmoid intussusception associated with rectal prolapse-a case report - Bogdan Socea, Anca Nica, Ovidiu Bratu, Camelia Diaconu, Alexandru Smaranda, Laura Socea, Serban Bertesteanu, Mihai Dimitriu, Alexandru Carap, Vlad Constantin - Archives of the Balkan Medical Union, Vol. 53, Iss. 1 2018

20. Superior vena cava syndrome - Paraschiv B, Dediu G, lancu A Bratu O, Diaconu C - Archives of the Balkan Medical Union, vol 52, No. 1, 2017

21. Radionuclide Imaging. An Update on the Use of Dynamic Renal Scintigraphy - Raluca Mititelu, Ovidiu Bratu - Modern Medicine, vol. 24, No. 4, 2017

22. Spiegel hernia - Case presentation - Bogdan Socea, Alexandru Smaranda, Anca Nica, Ovidiu Bratu, Camelia Diaconu, Laura Socea, Dan Dumitrescu, Mihai Dimitriu, Alexandru Carap, Vlad Constantin - Archives of the Balkan Medical Union, Vol. 53, Iss. 1,2018

23. Liver abnormalities in patients with heart failure - Teodora Draghici, Lucian Negreanu, Ovidiu Bratu, Radu Tincu, Bogdan Socea, Mihaela Iancu, Ana Maria Stanescu, Camelia Diaconu Archives of the Balkan Medical Union, Vol. 53, Iss. 1, 2018

24. Castleman`s Disease-Clinical, Histological and Therapeutic Features - Radu Dragos Marcu, Arsenie Dan Spinu, Bogdan Socea, Maria Oana Bodean, Camelia Cristina Diaconu, Florina Vasilescu, Tiberiu Paul Neagu, Ovidiu Gabriel Bratu - Revista de Chimie, vol. 2018, nr. 4, 2018

25. Taylor HS Endometrial cells derived from donor stem cells in bone marrow transplant recipients. JAMA 2004 Jul 7; 292 (1) 81-5

26. Mehedințu $\mathrm{C}$, Antonovici $\mathrm{M}$, Cîrstoiu $\mathrm{M}$, Brătilă $\mathrm{E}$, Comandașu $\mathrm{D}$ Berceanu C, Todea C. Endometriosis-Related Inflammation And Fertility. European Journal of Clinical Investigation, Vol 46, Supp 1, April 2016: 51

27. Carneiro MM, Pyramo Costa LM, de Avila I. To operate or not to operate on women with deep infiltrating endometriosis (DIE) before in vitro fertilization (IVF). JBRA Assist Reprod. 2017 AprJun; 21 (2): 120-125 
Elena-Silvia Nada et al.

28. Sanchez AM, Vanni VS, Bartiromo L, Papaleo E, Zilberberg E, Candiani M, Orvieto R, Vigano P Is the oocyte quality affected by endometriosis? A review of the literature. J Ovarian Res. 2017; 10: 43

29. Goud PT, Goud AP, Joshi N, Puscheck E, Diamond MP, Abu-Soud HM Dynamics of nitric oxide, altered follicular microenvironment, and oocyte quality in women with endometriosis. Fertil Steril. 2014 Jul; 102 (1): 151-159

30. Xu B, Guo N, Zhang XM, Shi W, Tong XH, Iqbal F, Liu YS Oocyte quality is decreased in women with minimal or mild endometriosis. Sci Rep. 2015 May; 5:10779

31. Santamaria X, Massasa EE, Taylor HS Migration of Cells from Experimental Endometriosis to the Uterine Endometrium. Endocrinology 2012 Nov; 153 (11): 5566-5574

32. Brătilă E, Stănculescu R, Baușic V, Comandașu DE. Efficacy of long-term Dienogest versus GNRH analogues treatment for endometriosis recurrency in premenopausal women. Maturitas 81, Issue 1 2015: 172

33. Senapati S Managing Endometriosis Associated Infertility. Clin. Obstet. Gynecol. 2011 Dec; 54 (4): 720-726

34. Coroleucă $C A$, Brătilă $E$, Brătilă $P$, Hudiță $D$, Stănculescu R, Comandașu D, Coroleucă CB. Lower urinary tract symptomatology in deep infiltrating and bladder endometriosis. Proceedings of UROGYN 2016 Filodiritto Publisher: 83-86

35. Mehedințu $C$, Diaconu $V$, Secureanu AF, Ionescu $S$, Brătilă $E$, Berceanu C, Cîrstoiu MM, Antonovici MR, Plotogea MN, Ionescu
OM. Laparoscopic Ureterolysis in the Management of Deep and Infiltrative Pelvic Endometriosis - Case Report. Proceedings of UROGYN 2016 Filodiritto Publisher: 164-169

36. Li X, Zeng C, Zhou YF, Yang HX, Shang J, Zhu SN, Xue Q Endometriosis Fertility Index for Predicting Pregnancy after Endometriosis Surgery. Chin Med J (Engl). 2017 Aug 20; 130 (16) 1932-1937

37. Brătilă E, Brătilă CP, Comandașu DE, Baușic V, Vlădescu CT, Mehedințu C, Berceanu C, Cârstoiu MM, Mitroi G, Stănculescu R The assessment of immunohistochemical profile of endometriosis implants, a practical method to appreciate the aggressiveness and recurrence risk of endometriosis. Rom J. Morphol Embryol 2015, 56(4): 1301-1307

38. Mehedintu C, Antonovici M, Brînduse L, Brătilă E, Stănculescu R, Berceanu C, Bratu O, Pițuru S, Onofriescu M, Mătăsariu DR. The Influence of Progesterone on Immunohistochemical Markers in Endometriosis. Rev. Chim. (Bucharest) 69 No. 32018

39. Brătilă E, Comandașu DE, Coroleucă CA, Brătilă P, Cîrstoiu MM, Berceanu C, Mehedintu C. Guiding the postoperative hormonal treatment in patients with endometriosis depending on the immunohistochemical profile of endometriosis implants. Gynecological Endocrinology 2016; 32(S1): 107

40. Rizk B, Turki R, Lotfy H, Ranganathan S, Zahed H, Freeman AR, Shilbayeh Z, Sassy M, Shalaby M, Malik R Surgery for endometriosis-associated infertility: do we exaggerate the magnitude of effect? Facts Views Vis Obgyn 2015; 7 (2): 109-118. 